\title{
Keep or Lose it: Mirroring Tana Sangkol in Madura Contemporary Literature
}

\author{
Erika Citra Sari Hartanto, Imron Wakhid Harits, Rif'ah Inayati \\ Universitas Trunojoyo Madura, Indonesia \\ Corresponding Author: erika.hartanto@trunojoyo.ac.id
}

\begin{abstract}
Ancestral land or tana sangkol in Madura is a significant material asset possessed by the Madurese people, with attached social and cultural values that link the living and the dead. Massive development on the island, however, has seen people selling their tana sangkol to foreign investors for conversion into shrimp ponds and hotels. This study aimed to analyze tana sangkol's representation in three short stories, "Anak Cangkul," "Kutukan Tanah Leluhur," and "Tanah Warisan," by Zainul Muttaqin, an author from Sumenep, Madura. The discussion mainly focused on the dramatic contribution of poverty to the sale of tana sangkol to investors, an act that is believed to bring bad luck to the sellers. Furthermore, tana sangkol epitomizes pride to the Madurese people, making them more willing to resist the intrusion of foreign investment. A qualitative research method with a close reading technique was applied and the data were analyzed using the post-colonial ecocriticism theory of Graham Huggan and Helen Tiffin. The results showed that there has been a shift in how the Madurese view their tana sangkol, with them no longer regarding it as sacred ancestral land. Moreover, it is considered to have social and cultural contexts due to its close relationship with the Madurese people's identity. Meanwhile, the oppression toward farmers is seen as structural and hierarchical.
\end{abstract}

Keywords: development; Madura; post-colonial ecocriticism; tana sangkol; Zainul Muttaqin

\section{INTRODUCTION}

Madura and its landmark, Suramadu Bridge, have attracted many visitors and massively affected people because it is more accessible and inexpensive than before. The regional development influences people's economic, social and cultural lives, though it also brings harm and disadvantages for the people and their ancestral land.

The land connects Madurese people to their ancestors and embodies their strong ties to cultural values. The people regard land as necessary with a sacred meaning, calling it posaka (Aziz, 2019, p. 1). Furthermore, the land is a generational heritage to the right person and is called tana sangkolan or tana sangkol. Wiyata stated that culturally, Madurese people highly respect and appreciate their parents' hard work through their integrity and loyalty in preserving their heritage land. Therefore, they do not want the land to fall into the hands of foreigners that do not know their history and ancestors because this means disavowal to their past. Additionally, selling their land is considered humiliating the ancestors and brings misfortune to the descendants or ecapo' tolana bangatowa (in Aziz, 2019, p. 2). This shows how the Madurese grandparents expected their younger generations to practice and apply the primary virtue of respecting elders and preserving the ancestral land, which ties closely to their lives and represents their identity (Mutmainnah, 2019). Therefore, it is an asset and belongs to the community's identity (Birch, 2005; Dzulkarnain, 2016; Kroplewska, 2017).

Land selling to foreign investors from China to build and develop industry creates concern from religious 
leaders or Kyai in Madura. They hold convocations and demand specific regulations from the government in Sumenep to prevent land selling (Zai, 2016). However, KH. A. Dardiri Zubairi stated that tana sangkol is no longer sacred but merely an object sold by people. As a result, it is fully conceived as an interchangeable object (Zubairi, 2020, p. 47).

Conflicts emerge as foreign investors find difficulties in acquiring land. Many Madurese people oppose the construction plans, refuse and ignore the investors' offering. Therefore, the investors use deceitful ways and violent methods to confiscate the lands by working together with farmers' leaders. Therefore, it is necessary to analyze the tana sangkol issues portrayed by many Madurese authors in their literary works. One of the authors is Zainul Muttaqin from Sumenep, Madura and a graduate from Pondok Pesantren Annuqayah, Guluk-Guluk, Sumenep. Myriad national media have published Zainul Muttaqin's short stories and poems. Zainul Muttaqin has received many awards, and 20 short stories are collected into Celurit Hujan Panas (2020). As a writer born and raised in Madura, Zainul Muttaqin's short stories are rich and closely related to the local aspect around Madura. The mythology includes carok, tana sangkol, a woman's body (Nurfadillah, 2019; Wijdaniyah \& Hasalah, 2020), and local wisdom emphasized by Madurese spirituality (Farida \& Andalas, 2019). Another evident aspect is hegemony and domination (Jannah, 2019).

Zainul Muttaqin scrutinizes the poverty's contribution to the sale of tana sangkol, Madura's development, and the farmers' resistance in three short stories, "Anak Cangkul," "Kutukan Tanah Leluhur," and "Tanah Warisan." Furthermore, Zainul Muttaqin vigorously depicts the complex problems of farmers and their heritage land in dealing with development.

"Anak Cangkul" narrates a flawed male protagonist, Maksar, that lives with their father, Karso. Due to poverty, many families often reject Maksar's proposal to marry their daughter. Moreover, Maksar's girlfriend, Martini, leaves Maksar to work as a migrant worker like other farmers because of fear of poverty. Maksar's neighbors sell their tana sangkol to investors to support their migrant occupations. The investors build supermarkets and shrimp pond industry. Therefore, many people convince Maksar to work remotely, though Karso refuses. Instead, Karso opens Maksar's mind about the cultural view of tana sangkol. The story ends with Maksar proud for not selling the family's heritage land.

In "Kutukan Tanah Leluhur," Zainul Muttaqin talks about a Madurese protagonist named Maksan, whose heart and mind are destroyed by his wife's anger for refusing to sell their ancestral land. The wife wants Maksan to sell the land because a buyer from town offers much money. This is because Maksan's wife is tired of living in poverty. However, Maksan persists in selling the land because it is ancestral. Maksan believed that selling ancestral land brings consequences, such as bad luck. However, Maksan's friend, Sukam, sold their land to the investor that built a hotel. Sukam receives much money but still lives a poor life and borrows money from Maksan when the wife is ill. The story ends with Maksan giving money to Sukam. Subsequently, Sukam feels shame about their life and regrets selling their ancestral land.

"Tanah Warisan" narrates several people forcing farmers to sell their land. One of them is Pak Lurah and their friend, Sarkab, whose job is to convince and persuade farmers to sell their ancestral land. Sukib, one of the farmers, initially refuses Sarkab's offers but is eventually lured by a huge amount of money to sell their ancestral land. As a result, many farmers sell their land to Sarkab, except Sulaep and the wife, Mastini. Sulaep insists against selling land because it is ancestral land. The story ends with Sulaep dying, and their dead body is found by farmers in their land. Pak Lurah and Cukong paid people to kill Sulaep at night. Also, Sarkab visits Sulaeb's house and deals with Mastini's refusal to sell the land.

The research problem is the representation of tana sangkol in three short stories by Zainul Muttaqin. It examines post-colonial ecocriticism's application since the stories capture the conflicting land issues in the name of development. This was discussed by Graham Huggen and Helen Tiffin in their book, Postcolonial Ecocriticism: Literature, Animal, Environment. Also, the social and cultural contexts of tana sangkol in Madura are provided to support or strengthen the analysis.

The study on the relation between post-colonial and ecocriticism has attracted many scholars in the twenty-first century (Echterling, 2016; Miller, 2012). The ecocriticism theory focuses on the American and British nature of writings. However, it fails to acknowledge local, marginalized natures (Egya, 2021; Nixon, 2005). Post-colonial studies base their concerns on cultural and literary criticism of non-Western or colonized people (Huggan \& Tiffin, 2007)environmental impact in the form of disease Á human, plant and animal Á forest felling, the casual or systematic slaughter of indigenous animals, and the introduction of European crops and livestock were both prime cause and continuing consequence of environmental change incurred through the post-1492 European diasporic intrusions (Crosby 1986. In contrast, 
post-colonial criticism, which involves environmental problems, is called green post-colonialism (Huggan \& Tiffin, 2007, p. 9)environmental impact in the form of disease Á human, plant and animal Á forest felling, the casual or systematic slaughter of indigenous animals, and the introduction of European crops and livestock were both prime cause and continuing consequence of environmental change incurred through the post-1492 European diasporic intrusions (Crosby 1986

Afzal stated that post-colonial ecocriticism studies the environment as a body composed of humans, animals, and land. It redirects critical thinking towards the relationship between humans (indigenous and foreign), land, humans, and nonhumans (2017)from the beginning, writers were exclusively engaged presenting nature as source of inspiration and a privilege to evolve their ideas and pen them down. With the introduction of the term Ecocriticism in literary criticism by the Association of the Study of Literature and Environment (ASLE. Additionally, Banarjee stated that this theory is inextricably connected to indigeneity and the necessity of perceiving land as an object of exploitation and a protagonist (2016, p. 194). This explanation means that post-colonial ecocriticism deals with the impact of colonizers toward colonized people, or the natives, and their environment. Therefore, the significant position of the environment, especially the land, is a unifying concept in the life of natives. The natives have been closely connected to their land because it represents their social and cultural life and identity. However, the capitalist and regimes' exploitation and mistreatment of land have erased and changed the natives' lives. They are denied the access to advance their life while maintaining their values. In this context, postcolonial ecocriticism links to the marginalized natives because they have the right and strive to sustain their water and land as their resources.

Huggan and Tiffin stated that one central task of post-colonial ecocriticism is to contest and provide viable alternatives to Western development ideologies. These contestations have mostly been consistent with radical Third-Worldist critiques that perceive development as neocolonialism. Development is a vast apparatus designed to serve the economic and political interests of the West (2010, p. 27). Therefore, post-colonial ecocriticism offers a different perspective of development because it works as neocolonialism in marginalized countries. Financial capital and power become the weapon to colonize thirdworld countries. However, development, which should enhance many people's lives, is destructed because it is intended to satisfy people with money and power. Exploiting the natives' cultural materials and property involves a collaboration between the national and local governments. This was captured by Esteva and Spybey, which stated that modern (post-war) development finds new ways of instantiating the exploitation through the collaboration between national governments and gargantuan transnational companies. In this case, the economies of gargantuan transnational companies exceed those of all but the largest developing countries. Also, their financial and technical assistance is provided in terms that continue to favor the West (in Huggan \& Tiffin, 2010, p. 30).

The collaboration has created the abuse of power that afflicts the natives. Consequently, the states and developmentalists have politically oppressed, marginalized, and exploited the natives. Furthermore, Grace emphasized that the developmentalist language of opportunity, backed up by money and power, is dispossession, and its nativist counterpart is resistance founded on the perceived entitlement to live where one traditionally belongs (Huggan \& Tiffin, 2010, p. 70). Therefore, there are significant differences between the developmentalist and the natives regarding language, action, and goal. The developmentalist or the colonialist speaks with the language of dispossession, acts aggressively, and is supported with much money and unlimited power to conquer the natives to achieve glory and victory. However, their language meets its opponent from the natives that willingly resist their entitlement to maintain their life and sovereignty. The natives speak with a caring and nurturing language to live harmoniously within the human and non-human realm, which implies simplicity.

The developmentalist's view is that land belongs to people and could be traded or transformed to suit their immediate purposes. In contrast, the nativist view is that people belong to the land, which holds them in their trust and requires their care and custodianship (Huggan \& Tiffin, 2010, p. 70). Moreover, these differences in understanding have brought up various treatments and handling in dealing with the natives' cultural and social lives. The developmentalists view land as non-substantial and could be adjusted in their favor. However, the natives regard their land as valuable material and possession because it completes their lives and connects them to their ancestors. Therefore, they praise the land by caring for and preserving it.

Having ancestral land is as important as having money for some people. An ancestral land is a place for cultivating, inhabitation and holds another meaning and value. Suhartono and Mutmainnah found that land could be a source of power, security guarantee, and a place 
to preserve and develop social and cultural systems. Moreover, it is valuable for families that honor land in protecting the trust and legacy from parents, implying the need to maintain its existence (Mutmainnah, 2019, p. 122).

KH. A. Dardiri Zubairi is a Kyai that concerns about agrarian affairs in Madura. In Wajah Islam Madura, KH. A. Dardiri Zubairi wrote that tana sangkol, or ancestral land, was passed down from generations as gold. For Madurese people, tana sangkol has sacred meaning and value as a link between the living and the ancestors. Therefore, in Madurese culture, an unfortunate event would happen when the land is sold for no justified reasons. Furthermore, the land is only sold to the closest family because the owner would buy it back. However, the land has been stripped of its sacredness through the drastically changing mindset of Madurese people since the Suramadu construction. As a result, their view of the land is also altered (Zubairi, 2020, pp. 47-48).

Suhartono and Mutmainnah discussed this view in their research in Pademawu, Pamekasan, Madura. They stated that society had experienced a shift in the meaning of inherited land and many people no longer believe in its sacredness. On the contrary, they consider that their inherited land could be traded to anyone and sell it to fulfill their necessities (Mutmainnah, 2019, p. 124).

The belief that the ancestral land contains sacred values was emphasized by KH. A. Dardiri Zubairi. In an interview with Radar Madura, KH. A. Dardiri Zubairi stated that in Madurese tradition, tana sangkol, or heritage land, connects the living to the dead. Many elders were buried in the heritage land and were not sold randomly when passed down to the next generation. In the past, there was a term of teko etolai, meaning or afraid of misfortunes (RadarMadura.id, 2021).

This study applied qualitative research method with a post-colonial ecocriticism theoretical approach. Primary data on the representation of tana sangkol were obtained from three short stories, "Kutukan Tanah Leluhur," "Tanah Warisan," and "Anak Cangkul," written by Zainul Muttaqin. Secondary data were sourced from books, a video, and articles relevant to the problems. The data were analyzed by applying post-colonial ecocriticism theory before interpretation conclusions were made.

\section{FINDINGS AND DISCUSSION Poverty and Development}

Madura Island is one of the regions in East Java with high poverty levels (Susilowati et al., 2020), and poorly educated people (Nooteboom, 2015, p. 31). Susilowati et al. (2020) stated that the number of poor people in four districts on the island of Madura exceeds the average number of poor people in East Java province. This shows that the four regencies are the most significant contributors to the number of poor people in East Java (2020, p. 176). Furthermore, it means that the people live in low-level economic conditions as fishers and farmers. The three short stories portray how some characters are tired of living in poverty. Consequently, investors consider this circumstance an opportunity to persuade the people to sell their tana sangkol.

In Zainul Muttaqin's "Kutukan Tanah Leluhur," the wife of protagonist Maksan forces the husband to sell their only land because investors are willing to buy people's land at high prices. The wife even threatens Maksan by divorcing when Maksan refuses to sell the land.

"Kebringasan istrinya bermula saat air liurnya jatuh
mendengar sejumlah harga tanah yang ditawarkan
padanya. Sepetak tanah dihargai setara dengan
satu hektar sawah di bawah bukit Garincang.
Perempuan mana yang tak tergiur menjual sepetak
tanah yang berada dekat pantai berpasir putih
ditumbuhi rindang cemara udang itu. Lebih-lebih
istrinya tak lagi sanggup makan nasi jagung dengan
lauk teri. Sekali-kali tenggorokannya perlu diberi
makanan lezat yang ia idam-idamkan selama ini."
(Muttaqin, 2020, p. 126)

"Her wife's anger began when her saliva fell as she heard the land's price being offered to her. A piece of land is valued at the equivalent of one hectare of rice fields under Garincang hill. Which woman is not tempted to sell a piece of land near a white sandy beach overgrown with shady cypress trees. Moreover, her wife is bored eating corn rice with anchovies as a side dish. Every now and then, her throat needs to be given delicious food she has been craving for all this time." (Author's translation)

In "Tanah Warisan," Zainul Muttaqin depicts Sukib, one of the characters that eventually sell the land because the investor and broker offer much money. They persuade the farmers that the money could sustain them for seven generations. As a result, many farmers sell their lands to the investors for the shrimp pond industry (2020, p. 134).

These short stories show that poverty becomes an opportunity for investors to offer money. They tempt the farmers with rich life, where they could buy and provide 
everything to support their living. The investors and their money persuade the farmers dissatisfied with their life. The better life that the farmers have dreamed of would be accomplished.

Zainul Muttaqin presents people's view that better life means having expensive and modern materials, and they do not have to strive hard in their fields and land. "Anak Cangkul" portrays the conversation between Maksar and their father, Karso, when they see their neighbors' lifestyles selling their lands to the investors.

“Untuk apa?” Karso melihat anak lelakinya.

"Biar bisa seperti mereka, Pak."

"Memangnya mereka bisa apa?"

"Mereka bisa bangun rumah megah, beli mobil, dan tak repot-repot lagi pergi ke ladang." (Muttaqin, 2020, p. 92)

"For what?" Karso stare at his son

"So I can be like them."

"What they can do, actually?"

"They are able to build luxury house, buy car, and they don't have to work in the fields." (Author's translation)

This conversation highlights the jealousy over the luxurious materials and modern life led by the other farmers. It reveals Maksar's inner dream of a better and more convenient life since their family has lived in poverty probably for the rest of their lives. Furthermore, Zainul Muttaqin portrays how the farmers are bored and sick of their low-level condition. "For them, rice fields and land were no longer reliable. Working in the fields, planting rice for years has never made them rich or even building a luxurious house." (2020, p. 90). The condition makes the other farmers sell their tana sangkol, their only property.

This proves that Madura has become one of the places in East Java with a low-level economy. Therefore, the government considers it necessary to resolve poverty by building industries and factories. Nevertheless, the development does not recognize the main issues of its people that upheld cultural and social lives, but only profits the government and the investors. This is in line with Huggan and Tiffin's statement that one concern within post-colonial ecocriticism is unveiling the ideology of western development. It perceives development as disguised neocolonialism, a vast apparatus designed to serve the economic and political interests of the West (2010, p. 27). This means that the development in the third-world countries, precisely in Madura, is neo- colonialism that mainly satisfies the West's desire for economic and political benefits.

They are colonized not by weapon and arms but by money and power. Additionally, the investors deliberately collaborate with the state's apparatus in colonizing the natives' land. This is visible in "Tanah Warisan," where the main character Sulaeb dies because the investors think Sulaeb hinders their wish to dominate the land and control the people. Sulaeb's dead body is found in their rice field.

"Tidak ada yang tahu malam itu, di antara gerimis yang mirip helai rambut jatuh di atas batang padi, dari kejauhan Pak Lurah memandangi pembantaian Sulaeb. Tak mau terlibat. Membuang muka. Geram. Juga berdiri cukong itu di sampingnya. Membuang asap rokoknya ke udara. Terdengar suara Sulaeb di antara tarikan napasnya yang terakhir. Gelap menyungkup seluruh permukaan langit. "Sudah selesai!" Kata Pak Lurah. Cukong itu tersenyum puas. Buru-buru mereka meninggalkan sawah. Tak ingin dilihat orang." (Muttaqin, 2020, p. 136)

"Nobody knew that night, between the drizzle that looked like strands of hair falling on top of rice stalks, from a distance, the village head watched Sulaeb's massacre. I do not want to get involved and be turned away. Furious. Also stood the investor next beside him. Remove the cigarette smoke into the air. There was Sulaeb's voice between his last breaths. Dark covers the entire surface of the sky. "Already completed!" The head of the village said. The investor smiled with satisfaction. They hurriedly left the fields. Do not want to be seen by people." (Author's translation)

First, this proves the absence of the state as the institution that protects its citizen. The character of the village's head symbolizes the state that politically abuses instead of defending the farmers. In the story, the character uses their power to silence the voices that reject the authority's demand. Second, the farmers are victims of their people and non-natives.

\section{The Impact of Selling Tana Sangkol}

The Suramadu Bridge functions as the gate for investors to come and offer much money in the name of regional development. The investors sell the false, short dream of becoming wealthy. As a result, the farmers sell their land, their only precious commodity, and witness the construction of supermarkets, shrimp ponds, and hotels within months. However, they soon realize that the 
regional development promised by the investors for their welfare is mere promises. They do not achieve well-being but remain in the same condition as before, where they even borrow money to support their needs. For instance, in "Kutukan Tanah Leluhur," Sukam comes to Maksan's house to borrow money because their wife is ill.

"Bukannya kau salah satu orang yang tanahnya dijual di pinggir pantai itu? Setahuku harga tanahmu sangat mahal. Apa sudah habis uangmu?" Maksan menguji kejujuran macam apa yang akan keluar dari mulut lelaki dekil itu. "Entahlah. Uang itu habis tak tahu ke mana. Aku sendiri tak paham bagaimana mungkin uang sebanyak itu cepat habis. Padahal, aku berusaha menggunakannya sebaik mungkin.” (Muttaqin, 2020, p. 129)

"Aren't you one of those people who sell their land by the beach? As far as I know, the price of your land is costly. Have you run out of money?" Maksan tested what kind of honesty would come out of a dirty man's mouth. "I have no idea. The money ran out. I don't know where. I myself do not understand how that much of money can run out very quickly. In fact, I am trying to use it as best as I can." (Author's translation)

This evidence emphasizes the notion of Western ideology and development that does not bolster Madurese people's roles and competencies because of the shift in their lifestyle. For years, the people have lived in traditional and cultural modes and systems. However, the industry's existence has changed their way of life, though they are not ready for the changes. This is in line with Rifai's statement that the anxiety among the people after the Suramadu Bridge construction is due to two reasons. The development involves skilled persons from other regions and is not carried out as a whole set of activities (Rifai, 2007, p. 466). Moreover, Madurese people belong to relatively neglected groups regarded as unskilled workers with low-paying jobs (Nooteboom, 2015)

The impact of selling tana sangkol is immediately felt by Sukam by experiencing miserable life and runs out of money. Therefore, Maksan says to Sukam:

"Kau sudah dikutuk karena tak seharusnya tanah itu dijual. Tanah yang kita miliki di tepi pantai itu tak sepantasnya kita jual. Kutukan lain menimpamu sekarang adalah kau menjadi jongos di atas tanah sendiri. Kita bisa terusir dari tanah sendiri karena pikiran hanya disumpal uang. Coba pikirkan bagaimana anak cucumu kelak," Kalimat panjang berderai dari mulut Maksan persis seperti hujan yang jatuh dari langit." (Muttaqin, 2020, p. 129)

"You have been cursed because the land was not supposed to be sold. We should not sell the land on the beach. Another curse on you now is that you become a servant on your land. We can be driven out of our land because our thoughts are only filled with money. Just think about how your children and grandchildren will be." Long words run from Maksan's mouth just like rain falling from the sky" (Author's translation)

The word "cursed" from the excerpt refers to the farmers' condition after selling their tana sangkol to investors. They own no business but work as subordinate employees of the investors.

Many Madurese people no longer believe in the land's sacredness. However, Zainul Muttaqin shows that tragic destiny befalls characters that sell their ancestral land by becoming servants on their land. Through Maksar in "Anak Cangkul," Zainul Muttaqin voices concern upon the farmers rampantly selling their tana sangkol.

"“Minimarket itu dibangun di atas tanah yang kau jual, begitu pun tambak udang itu dibangun di atas tanah mereka yang sudah dijual. Apa itu yang kau banggakan? Menjadi budak di atas tanah sendiri. Begitukah caramu mencintai kampong sendiri?' Maksar menekan suaranya." (Muttaqin, 2020, p. 94)

"Minimarket is built on the land you sell, so the shrimp pond is also built on the land they have sold. Is that what you are proud of? Become a slave on one's land? Is that how you love your village?' Maksar suppressed his voice." (Author's translation)

Another protagonist concerned about their neighbors' destiny after selling tana sangkol is Maksan in "Kutukan Tanah Leluhur."

"Tanah-tanah itu disulap menjadi bangunan menjulang tinggi. Bibir pantai dikelilingi penginapan mewah tempat para pelancong bermalam. Warga menghidupi anak dan istrinya dari bekerja sebagai pelayan di atas tanah yang dulunya milik mereka. Sekilas pikiran ini mengusik Maksan...JJantung Maksan terasa 
ditikam kesedihan tatkala mata lamurnya melihat tetangganya bekerja hingga larut malam hanya sebagai jongos pada rumah penginapan yang berdiri kokoh di tepi pantai tersebut." (Muttaqin, 2020, pp. 127-129)

"The lands were transformed into towering buildings. The beach is surrounded by luxury inns where travelers spend the night. The villagers support their children and wives from working as servants on land that used to belong to them. At first this thought bothered Maksan... Maksan's heart was like stabbed with sadness when his old eyes saw his neighbor works late into the night just as a housemaid at the inn that stood firmly on the beach." (Author's translation)

Zainul Muttaqin, a Madurese author, living in Sumenep, witnesses the phenomena of tana sangkol and shows the readers that such ironic situations are suffered from the development in their villages. Moreover, Zainul Muttaqin narrates how people work as employees in hotels, supermarkets, and shrimp pond industries built on their land, becoming slaves in their tana sangkol. They lack access and power to decide their life in the future, meaning they are truly marginalized. This is in line with Huggan and Tiffin, which stated that third-world countries are denied access to the profits of their resources (2010, p. 2).

Another impact is that the farmers later lack land for cultivation but work to meet their daily needs. As a result, they leave for another region or country to get a job. In "Tanah Warisan," Zainul Muttaqin portrays Sulaeb, the main character that observes their village condition after many neighbors sell their land to the investors, stating;

"Kini, orang-orang mulai meninggalkan kampong halaman. Satu per satu masuk ke dalam bus yang membawanya ke Jakarta. Mereka tak lagi dapat menggarap sawahnya...Lama-lama kita jadi budak di kampong sendiri. Lama-lama pula semua orang pergi dari kampungnya sendiri," kata Sulaeb kepada Mastini, istrinya...Mereka tergiur dengan jumlah uang yang ditawarkan cukong itu. Namun, ia tak pernah berpikir, apa nasib anak cucu kita kelas kalau tak ada sepetak sawah pun yang kita miliki." (Muttaqin, 2020, pp. 135-136)

"Now, people are starting to leave their hometowns. One by one, they got into the bus that was taking them to Jakarta. They can no longer cultivate their land. Gradually we became slaves in our village. Gradually everyone leaves their village," said Sulaeb to Mastini, his wife... They are tempted by the amount of money the cukong is offering. However, they never thought, what will the fate of our children and grandchildren be if we do not have any rice fields." (Author's translation)

Development should involve the people in the targeted area to increase their skills, broaden their minds, and enhance their life quality. However, Western ideology does not always address the core problems in marginalized societies that bear the consequences. In the short stories, some of the characters become slaves or servants in the industries or hotels built on their land, assuming positions of unskilled workers (Nooteboom, 2015, p. 282). They are deprived and uprooted from their land, meaning that the developmentalists pursue maximum benefits without considering Madurese people's existing social and cultural values. As a result, the poorer majority are separated from traditional subsistence and denied access to the profits of their resources (Huggan \& Tiffin, 2007, p. 2)environmental impact in the form of disease Á human, plant and animal Á forest felling, the casual or systematic slaughter of indigenous animals, and the introduction of European crops and livestock were both prime cause and continuing consequence of environmental change incurred through the post-1492 European diasporic intrusions (Crosby 1986.

\section{Resistance and Identity}

Zainul Muttaqin's short stories show how development has colonized and destroyed the Madurese people and their social and cultural values. Consequently, the protagonists in the stories resist the investors' offering by refusing to sell their tana sangkol, even when other farmers sell their land. Additionally, the protagonists do not budge over their own family wishes to sell their tana sangkol.

In "Anak Cangkul," Karso convinces their son Maksar to work as a migrant worker as the other neighbors. Maksar's neighbor makes money and buys a car, something luxurious for their family. However, Karso refuses Maksar's proposal because the family has to sell their valuable tana sangkol.

"Karso mengambil napas, sejenak kemudian ia berujar pada Maksar, "Kalau mau bekerja jadi TKI, apa kau mau jual ladangmu itu? Tanah itu tidak boleh dijual berapapun harganya. Ajege tana ajege nak poto. Ingat itu, penting artinya." (Muttaqin, 2020, p. 92) 
"Karso takes a deep breath. A moment later, he says to Maksar, "If you want to work as a migrant worker, would you sell your precious land? The land may not be sold at any price. Ajege tana ajege nak poto. Remember that it matters." (Author's translation)

In "Kutukan Tanah Leluhur," the protagonist Maksan declines their wife's request to sell their tana sangkol, which angers the wife:

"Aku tak mau jual tanah itu, karena Ajhege nak poto e bhudi are," Maksan menekan suaranya. Terlampau kesal, istrinya masuk. Pintu dibanting oleh perempuan paruh baya itu hingga bahu Maksan terangkat." (Muttaqin, 2020, p. 128)

"I do not want to sell the land because of Ajhege nak poto e bhudi are," Maksan suppressed his voice. Too annoyed, his wife walked in. The middle-aged woman slammed the door until Maksan's shoulders lifted."(Author's translation)

Another evidence of Muttaqin's protagonist's resistance to selling their tana sangkol is in "Tanah Warisan." Sukib refuses Sarkab's persuasion to sell their tana sangkol.

"Seluruh warga di sini sudah menjualnya. Tinggal kau. Ayolah!"

"Karena mereka tak pernah tahu bagaimana cara ajege tana ajege nak poto. Tanahku tak kan pernah dijual. Tanah warisan. Tanah nenek moyang tak boleh dijual. Paham kau!'(Muttaqin, 2020, p. 135)

"All of the farmers here have sold their land, except you. Come on!"

"Because they never know how to ajege tana ajege nak poto. My land will never be sold. It is heritage land. The ancestral land cannot be sold. Understand!" (Author's translation)

Zainul Muttaqin emphasizes the meaning of Ajege tana ajege nak poto (preserving the land to protect the next generation) and Ajhege nak poto e bhudi are (looking after our next generation in the future). The words are mentioned several times in the short stories, implying the elders' awareness and concern for the young generation. This proves that Madurese elders perceive the land as a possession and a deep connection of their past and future. Therefore, their ancestral land should be cared for by the elders and their next generation. This supports Huggan and Tiffin's statement concerning the nativist view that people belong to the land, which holds them in their trust and requires their care and custodianship (2010, p. 70).

Tana sangkol links the present generation and their elders by relating their past, history, and identity. Their younger generation's existence and identity are sustained and rooted back to their elders and history. Hence, the resistance by the few farmers implies efforts to guard and preserve their elders, past, and identity. Moreover, the loss of tana sangkol indicates the loss of their identity as Madurese. This was emphasized by Mutmainnah's statement that the land functions as an asset for farming and identity as Madurese people. Therefore, when the people cannot defend their land, their existence cannot be sustained (2017, p. 20).

\section{CONCLUSION}

This study examined the significant meaning of land as a generational asset for the Madurese people. This land is called heritage land, or tana sangkol, on which many Madurese have buried their elders. As a result, social and cultural values connect the younger generations to their elders and their past.

The findings and discussion reinforce and support the theory of post-colonial criticism proposed by Huggan and Tiffin regarding the development of Western ideology in third-world countries. The development of Madura encompasses neocolonialism using unlimited money and abuse of power to marginalize its inhabitants. Many Madurese have lost their tana sangkol because investors offered them a large amount of money so they can establish hotels and develop a local shrimp pond industry. Moreover, the involvement of a corrupt state contributes to Madurese people becoming increasingly cornered. Consequently, the Madurese carry out resistance to these developments, in order to maintain their entitlement as guardians of their tana sangkol. This is part of caring for and preserving the land because it reveals their identity as Madurese.

\section{ACKNOWLEDGEMENT}

This research article is sponsored and fully funded by the Institute for Research and Community Service (LPPM) Universitas Trunojoyo Madura under the Grant by Contract No. 3152/UN46.4.1/PT.01.03/2021.

\section{REFERENCES}

Afzal, A. (2017). Ecocritical post-colonial studies on humans, land, and animals [Northern Iowa]. https:// 
scholarworks.uni.edu/etd/414

Aziz, A. (2019). Peran Kiai dalam Mempertahankan Tanah Sangkol [UIN Sunan Kalijaga]. http://digilib.uinsuka.ac.id/id/eprint/37780/

Banerjee, M. (2016). Ecocriticism and Postcolonial Studies. In H. Zapf (Ed.), Handbook of Ecocriticism and Cultural Ecology (pp. 194-207). De Gruyter. https:// doi.org/https://doi.org/10.1515/9783110314595-012

Birch, T. (2005). 'A land so inviting and still without inhabitants': erasing Koori culture from (post-) colonial landscapes. In G. Mather, K. Darian-Smith, L. Gunner, \& S. Nuttall (Eds.), Text, Theory, Space: Land, Literature, and History in South Africa and Australia (p. 171). Taylor\& Francis e-Library. https:// www.sahistory.org.za/sites/default/files/archivefiles/kate_darian-smith_liz_gunner_sarah_nuttall_ texbook4you.pdf

Dzulkarnain, I. (2016). Heterotopia Perang Kepemilikan Tanah Bagi Masyarakat Madura: Studi terhadap Gerakan Sosial Dekonstruksi Makna Tanasangkol. Gerakan Sosial Dan Kebangkitan Bangsa, May, 329-335. https://www.researchgate.net/ publication $/ 305810175$

Echterling, C. (2016). Post-colonial Ecocriticism, Classic Children's Literature, and the ImperialEnvironmental Imagination in The Chronicles of Narnia. Journal of the Midwest Modern Language Association, 49(1), 93-117. https://doi.org/https:// doi.org/10.1353/mml.2016.0016

Egya, S. E. (2021). 'Farmer-born peasant-bred': agriculture, modernity and socio-ecological vision in Niyi Osundare's Village Voices and The Eye of the Earth. Green Letters, 00(00), 1-14. https://doi.org/10.1080 /14688417.2021.1880331

Farida, N., \& Andalas, E. F. (2019). Eksistensi Kearifan Lokal Madura Di Era Modern Dalam Kumcer Celurit Hujan Panas Karya Zainul Muttaqin. Atavisme, 22(2), 217-232. https://doi.org/10.24257/atavisme. v22i2.581.217-232

Huggan, G., \& Tiffin, H. (2007). Green Postcolonialism. Interventions, 9(1), 1-11. https://doi. org/10.1080/13698010601173783

Huggan, G., \& Tiffin, H. (2010). Post-colonial ecocriticism: literature, animals, environment. In Taylor \& Francis e-Library. Routledge.

Jannah, M. (2019). Hegemoni Kekuasaan Pada Masyarakat Madura dalam Kumpulan Cerpen Celurit Hujan Panas karya Zainul Muttaqin. SENASBASA, 3, 650-658. http://research-report.umm.ac.id/index. php/SENASBASA/article/download/3222/2910

Kroplewska, E. (2017). "For not only do we lose everything if we lose our land. We also become nothing." The representation of land in contemporary New Zealand literature. Explorations: A Journal of Language and
Literature, 5(2017), 47-60. https://doi.org/10.25167/ $\exp 13.17 .5 .5$

Miller, J. (2012). Post-colonial Ecocriticism and Victorian Studies. Literature Compass, 9(7), 476-488. https:// doi.org/10.1111/j.1741-4113.2012.00891.x

Mutmainnah. (2017). AJAGA TANA AJAGA NA' POTO: Perlawanan Warga Lapa Taman Menghadapi Investor. In M. A. Hidayat \& K. Rosyadi (Eds.), Proceeding International Conference On Ethnicity and Globalization (pp. 15-23). Department of Sociology, University of Trunojoyo Madura. http:// sosiologi.trunojoyo.ac.id/wp-content/uploads/ Proceeding-ICEGO.pdf

Mutmainnah, S. and. (2019). Perubahan Makna Tanah Warisan Pada Masyarakat Desa Bunder Kecamatan Pademawu Kabupaten Pamekasan. Pama, 12(2), 122-127. https://doi.org/https://doi.org/10.21107/ pamator.v12i2.6286

Muttaqin, Z. (2020). Celurit Hujan Panas. PT. Gramedia Pustaka Utama.

Nixon, R. (2005). Environmentalism and Postcolonialism. In A. Loomba, S. Kaul, M. Bunzi, A. Burton, \& J. Esty (Eds.), Postcolonial Studies and Beyond (pp. 233251). Duke University Press. https://read.dukeupress. edu/books/chapter-pdf/96472/9780822386650-ix. pdf

Nooteboom, G. (2015). Forgotten People: Poverty, Risk and Social Security in Indonesia (The Case of the Madurese). KITLV. https://www.oapen.org/downlo ad?type $=$ document\&docid $=613356 \#$ page $=125$

Nurfadillah. (2019). Kajian Antropologi Sastra dalam Antologi Cerpen Celurit Hujan Panas karya Zainul Muttaqin [Universitas Muhammadiyah Sumatera Utara]. http://repository.umsu. ac.id/bitstream/123456789/5806/1/SKRIPSI NURFADILLAH.pdf

RadarMadura.id. (2021). Kiai A. Dardiri Zubairi Kampanyekan Jaga Kedaulatan dengan Pertahankan Tanah Sangkol. https://www.youtube.com/ watch? $\mathrm{v}=$ FnNZQex0kAI

Susilowati, D., Joko, S., \& Pramuja, R. A. (2020). Quality Study of Human Development and Poverty in Madura Island. Jurnal Ekonomi Pembangunan, 17(2), 175. https://doi.org/10.22219/jep.v17i2.10360

Wijdaniyah, E. J., \& Hasalah, M. (2020). Representasi Mitologi Madura. Sekolah Pascasarjana UPI. http:// riksabahasa.event.upi.edu/file/ppt/EKA_JUWITA_ WIJDANIYAH_Representasi_Mitologi_Madura.ppt Zai. (2016). Penjualān Tanah Kepada Investor Asing Marak, Tokoh Ulama Sumenep Adakan Pertemuan. Suaraindonesia_new.Com. https://suaraindonesianews.com/penjualan-tanah-kepada-investor-asingmarak-tokoh-ulama-sumenep-adakan-pertemuan/

Zubairi, A. D. (2020). Wajah Islam Madura. TareBooks. 